\title{
High doses of ascorbate (vitamin c): a new frontier in the treatment of intraocular cancer
}

\section{Introduction: retinoblastoma and Uveal melanoma}

Retinoblastoma is a rare intraocular tumour affecting the retina of young children and infants. ${ }^{1}$ Chemotherapeutic agents such as carboplatin and etoposide, have been shown to effectively reduce the volume of intraocular tumours in these children. ${ }^{2,3}$ However, the toxicity of systemic chemotherapy, still represents an issue which deserves further investigation, ${ }^{4,5}$ particularly when genomic instability is involved, as in the case of retinoblastoma. ${ }^{6,7}$ Uveal Melanoma is a malignant cancer of the uvea, affecting around 4.3-5 individuals per million, in the United States, the vast majority of which are Caucasian males. ${ }^{8}$ Despite its paucity, uveal melanoma is the most common primary tumour of the eye in adults, with the choroid as the most commonly involved anatomical structure. ${ }^{9}$ Up to $50 \%$ of patients develop metastatic disease in a time-lapse variable from five to 15 years after diagnosis, with preferential involvement of the liver, and about $90 \%$ of them will ultimately succumb to metastatic spread in less than three months. ${ }^{10-15}$

Until the late eighties, the only treatment available for uveal melanoma was enucleation of the affected eye, though brachytherapy, thermotherapy and radiation therapy can be used to treat small/ medium size tumours with preservation of the eye. ${ }^{16}$ Several different chemotherapeutic agents have been used, such as Dacarbazine, alone or in combination with Interferon- alpha $2 b$, after primary treatment, to patients at high risk of developing metastatic disease, but they have not improved the outcome of these patients. ${ }^{17,18}$ Globally, despite the improvements in the treatment of primary tumours and although very rarely patients show detectable metastasis at presentation, still half of the patients die of metastatic disease. Regarding the mechanisms of malignant transformation, in uveal melanoma, emphasis has been given to genetic changes, but, although both cytogenetics and genetics have enhanced prognosis, allowing the distinction of tumours with higher metastatic potential, metastatic disease remains the leading cause of death among patients with uveal melanoma. ${ }^{19}$ In recent years, Reactive Oxygen Species (ROS), the key mediators in oxidative stress, have emerged as promising targets for anticancer drug discovery and extensive research has documented a causative involvement of alterations of the Red-Ox (reduction/oxidation) balance in tumour progression, particularly for oncological indications with little treatment options, including metastatic melanoma. ${ }^{20-24}$

\section{The anticancer properties of vitamin $\mathbf{C}$ in high concentrations}

Among its innumerable physiologic properties, Vitamin C (in the form of both ascorbic acid or sodium ascorbate), when administered in high ("pharmacologic") concentrations, is toxic for cancer cells, both in vitroand in vivo, in a number of different ways. Although widely known as the founder of all antioxidants and free radical

\author{
Volume 4 Issue I - 2016
}

\author{
Domenico Mastrangelo, Lauretta Massai \\ Department of Surgical Medical Sciences and Neurosciences, \\ University of Siena, Italy
}

Correspondence: Domenico Mastrangelo, Department of Surgical Medical Sciences and Neurosciences, University of Siena, Italy, Email mastrangelo@unisi.it

Received: December 10,2015 | Published: January 08, 2016

scavengers, Vitamin C is cytotoxic for cancer cells, in vitro, mainly because of its pro-oxidant properties, ${ }^{25-33}$ and this activity seems to be primarily mediated by hydrogen peroxide; therefore, Vitamin $\mathrm{C}$ in pharmacologic concentrations is considered a prodrug of hydrogen peroxide. ${ }^{34-42}$ When oxidized, in biological systems, Vitamin C generates hydrogen peroxide, which can be considered a ROS; this action can be enhanced by divalent cations such as iron and copper. ${ }^{43-46}$ The amount of hydrogen peroxide generated is usually proportional to the amount of Vitamin $\mathrm{C}$ administered. ${ }^{47-50}$ However, other factors influence the formation of hydrogen peroxide, after administration of high doses of Vitamin C; in particular, cupric ion is a catalyst of the oxidation of Vitamin C, and, as such, it increases the production of hydrogen peroxide, starting from Vitamin C. ${ }^{51-54}$

The increased levels hydrogen peroxide, upon administration of Vitamin C, leads to accumulation of this ROS in cancer cells, which have amount of catalase of 10 -to 100 times lower than the normal ones, and this explains the selective toxicity of high concentration of Vitamin $\mathrm{C}$ for cancer cells, as compared to the normal ones..$^{55-60} \mathrm{In}$ addition to Vitamin $\mathrm{C}$ per se, some products of Vitamin $\mathrm{C}$ metabolism have shown anticancer properties; among others: dehydroascorbic acid, 2,3-diketogulonic acid, and 5-methyl 1-3,4-dehydroxytetrone. 27,28,60-63

Secondary anticancer properties of Vitamin C include:

I. Improved collagen synthesis with consequent limitation of cancer spread. ${ }^{64,65}$

II. Improved immune competence, through enhanced synthesis of immunoglobulin's, phagocytosis and production of interferon. ${ }^{66-69}$

III. Inhibition of prostaglandins and the release of arachidonic acid, which is supposed to represent a synergistic signal leading to cell proliferation..$^{70,71}$

IV. Stabilization of $\mathrm{p} 53$, a protein involved in the control of cell proliferation. $^{72,73}$ 


\section{Current chemotherapy for retinoblastoma and high doses of vitamin C: evidence from in vitro studies}

Chemotherapeutic agents such as carboplatin and etoposide, have been shown to effectively reduce the volume of intraocular tumours in children affected by retinoblastoma. ${ }^{74,75}$ However, the toxicity of systemic chemotherapy, still represents an issue which deserves further investigation, ${ }^{76,77}$ particularly when genomic instability is involved, as in retinoblastoma. ${ }^{6,7}$ In an effort to improve drug delivery to the tumour, and simultaneously reduce systemic toxicity, clinical researchers have more recently developed super selective Ophthalmic Artery Infusion (SOAI) of chemotherapeutic agents ${ }^{78}$ which, although still controversial, ${ }^{79,80}$ promises a dramatic improvement in the rate of preservation of the affected eyes,81-83 particularly when different drugs are combined. ${ }^{84-86}$

Although widely used, chemotherapy of retinoblastoma is based on studies testing only a few chemotherapeutic agents ${ }^{87,88}$ using the clonogenic assay, which has been largely criticized, in the past ${ }^{89,90}$ and almost completely abandoned nowadays, given its low reliability. ${ }^{91}$ More recently, the combination of carboplatin and cell immunotherapy has been demonstrated superior to carboplatin alone, in killing Y79 cells $^{92}$ and carboplatin-resistant retinoblastoma cells in vitro[93]. However, even at its best, cancer chemotherapy has limited value in the treatment of retinoblastoma while in vitrotesting on Vitamin C, has already shown promising results and a clear superiority, when compared to conventional chemotherapy.

As a matter of fact, Medina and Schweigerer, in 1993-4, showed that Ascorbate has cytotoxic effect on Y79 cells in long-term incubations in the presence of limited amounts of serum in the medium, ${ }^{94,95}$ while other Authors have demonstrated that a mixture, containing, among others, ascorbic acid, induces apoptosis on Y79 cells, in vitro. ${ }^{96}$ In our experience, Y79 cells are highly sensitive to sodium ascorbate, when exposed to this vitamin for only one hour, under standard culture conditions (RPMI 1640, supplemented with antibiotics, Glutamine, $10 \%$ heat inactivated Fetal Bovine Serum in an atmosphere of $5 \%$ $\mathrm{CO} 2$ and $95 \%$ air). In particular, after exposure for one hour to millimolar (mM) concentrations of sodium ascorbate, about $90 \%$ of Y79 cells in culture died, at a concentration of Vitamin C of $5 \mathrm{mM} \cdot{ }^{97}$ Melphalan at the standard dose, used to treat retinoblastoma, had no effect on Y79 cells treated for comparison. The rationale behind the use of ascorbate in the treatment of retinoblastoma, is not only to be found in the metabolic properties of this molecule, but also on evidence showing that a maternal diet and nutrition rich in vegetables and fruits, may prevent the development of this tumour. ${ }^{98}$ On the other hand, the role of ROS in the genesis of retinoblastoma is very well known and documented by different Authors. ${ }^{99-101}$

\section{Current chemotherapy for uveal melanoma} and high doses of vitamin c: evidence from in vitro studies

When uveal melanoma is limited to the eye, surgical resection may lead to some improvement of the overall survival; ${ }^{102}$ other forms of local treatment applied to uveal melanoma, are: intra-arterial chemotherapy, trans-arterial percutaneous chemoembolization, selective internal radiation therapy, and radiofrequency ablation. ${ }^{103}$ However, as previously mentioned, up to $50 \%$ of patients develop metastatic disease, with spread of tumour cells to liver (89\%), lung (29\%), bone (17\%), and other organs, ${ }^{104,105}$ and this event represents a clear indication to systemic chemotherapy. Unfortunately, although various chemotherapeutic agents have been tested so far, like dacarbazine, fotemustine, or gemcitabine/treosulfan, the impact of systemic chemotherapy on patients' survival is questionable. ${ }^{106,107}$

Skin melanoma is supposed to depend on exposure to ultraviolet light, ${ }^{108,109}$ but the evidence of the role of ultraviolet light in the pathogenesis of uveal melanoma is still controversial. ${ }^{110,111}$ However, it is quite clear that both uveal and skin melanoma, depend on a dysregulation of the cellular Red-Ox state ${ }^{112-115}$ with an increase in the production of ROS, which represents an indication for prevention with antioxidant and treatment with pro-oxidant molecules, a role which can be fully interpreted by ascorbate, depending on the dose administered. In our experience, uveal melanoma cell lines (C918 and OCM1) exposed for two hours to increasing concentrations of ascorbate in the culture medium, are highly sensitive to the cytotoxic effects of the vitamin. In particular, at $7 \mathrm{mM}$ of sodium ascorbate in the medium, the percentage of live cells is well below the $10 \%$, and, in most cases, below the 5\%. Arsenic Trioxide (ATO), which is known to induce apoptotic/necrotic cell death through production of hydrogen peroxide $(\mathrm{H} 2 \mathrm{O} 2)$, has been used in phase II clinical trials in uveal melanoma, even if with limited results; ${ }^{116}$ interestingly, in our experience, adding arsenic trioxide to the culture, significantly increased the cytotoxic effects of ascorbate on uveal melanoma cell lines. ${ }^{117}$

\section{Concluding remarks}

In spite of the great number of reports showing a strong anticancer activity of high concentration of ascorbate in vitro ${ }^{118,119}$ the in vivo antitumor effect of high doses of the vitamin is still controversial and further controlled clinical trials are needed to fully elucidate it. However, ascorbate administered in high doses by intravenous route, has great potentialities in the treatment of cancer, once a few technical issues are further clarified.In a recent, excellent review on this matter, Gonzalez and Coll. enumerate the variables that may interfere with the clinical response to high doses of intravenous ascorbate. ${ }^{120}$ In particular the Authors underscore the level of tissue oxygenation, the level of blood glucose, and the physiological Red-Ox balance, as the most relevant physiological/cellular variables to take into account, to fully exploit the anticancer potential of high doses of ascorbate in vivo. In 1956, Otto Warburg clarified that cancer cells are metabolically different from their normal counterpart, since they not only survive under adverse conditions such as hypoxia, but are also capable of proliferation and distant invasion (metastasis). ${ }^{121,122}$

The so called "Warburg effect" (or phenomenon), is represented by a metabolic shift which compels cancer cells to rely on the inefficient glycolytic mode of ATP synthesis (2 ATPs/glucose), rather than respiration that produces substantially more ATP/glucose (about 36 ATPs/glucose). As a consequence, cancer cells must adopt a mode of increased glucose import to meet their energy demands, and this explains why they increase their levels of glucose transporters (GLUT) $^{123}$ and crave for glucose. ${ }^{124-127}$ Taken together, these data indicate that, since high concentrations of ascorbate seem to kill cancer cells essentially by increasing the local production of hydrogen peroxide (H2O2), it is clear that a good local oxygenation and a reduced intake of glucose are fundamental pre-requisites to optimize the cytotoxic effect of the vitamin on cancer cells. Once optimized 
as suggested by the metabolic changes occurring in cancer cells, the intravenous injection of high doses of Vitamin C promises to radically improve the outcome and the quality of life of patient affected by both retinoblastoma and uveal melanoma, since:

I. In both its oral and intravenous (IV) formulations, ascorbate is remarkably safe.

II. It improves the quality of life of cancer patients.

III. It reduces the many complications of the disease.

IV. It enhances the cytotoxic effects and reduces the side effects of chemotherapy.

V. As a pro-drug of hydrogen peroxide, it is toxic only for cancer cells.

\section{Acknowledgments}

None.

\section{Conflicts of interest}

No conflicts to declare.

\section{Funding}

None.

\section{References}

1. Gutman FA. The natural course of active choroidal lesions in the presumed ocular histoplasmosis syndrome. Trans Am Ophthalmol Soc. 1979;77:515-541.

2. Mastrangelo D, De Francesco S, Di Leonardo A, et al. The retinoblastoma paradigm revisited. Med Sci Monit. 2008;14(12):RA231-240.

3. Friedman DL, Himelstein B, Shields CL, et al. Chemoreduction and local ophthalmic therapy for intraocular retinoblastoma. $J$ Clin Oncol. 2012;18(1):12-17.

4. Rodriguez-Galindo C, Wilson MW, Haik BG, et al. Treatment of intraocular retinoblastoma with vincristine and carboplatin. J Clin Oncol. 2003;21(10):2019-2025.

5. Leahey A. A cautionary tale: dosing chemotherapy in infants with retinoblastoma. J Clin Oncol. 2012;30(10):1023-1024.

6. Rizzuti AE, Dunkel IJ, Abramson DH. The adverse events of chemotherapy for retinoblastoma: what are they? Do we know? Arch Ophthalmol. 2008;126(6):862-865.

7. van Harn T, Foijer F, van Vugt M, et al. Loss of Rb proteins causes genomic instability in the absence of mitogenic signaling. Genes Dev. 2010;24(13):1377-1388.

8. Lefèvre SH, Vogt N, Dutrillaux AM, et al. Genome instability in secondary solid tumours developing after radiotherapy of bilateral retinoblastoma. Oncogene. 2001;20(56):8092-8099.

9. Singh AD, Topham A. Incidence of uveal melanoma in the United States: 1973-1997. Ophthalmology. 2003;110(5):956-961.

10. Katz NR, Finger PT, McCormick SA, et al. Ultrasound biomicroscopy in the management of malignant melanoma of the iris. Arch Ophthalmol. 1995;113(11):1462-1463.

11. Hawkins BS, Collaborative Ocular Melanoma Study Group. The Collaborative Ocular Melanoma Study (COMS) randomized trial of pre-enucleation radiation of large choroidal melanoma: IV. Ten-year mortality findings and prognostic factors. COMS report number 24. Am J Ophthalmol. 2004;138(6):936-951.
12. Collaborative Ocular Melanoma Study Group. The Collaborative Ocular Melanoma Study (COMS) randomized trial of pre-enucleation radiation of large choroidal melanoma II: initial mortality findings. COMS report no. 10. Am J Ophthalmol. 1998;125(6):779-796.

13. Rajpal S, Moore R, Karakousis CP. Survival in metastatic ocular melanoma. Cancer. 1983;52:334-336.

14. The Rotterdam Ocular Melanoma Study Group, Koopmans AE, de Klein Am, et al. Diagnosis and management of uveal melanoma. Eur Ophthal Rev. 2013;7(1):56-60.

15. Einhorn LH, Burgess MA, Gottlieb JA. Metastatic patterns of choroidal melanoma. Cancer. 1974;34()4:1001-1004.

16. Mavligit GM, Charnsangavej $\mathrm{C}$, Carrasco $\mathrm{CH}$, et al. Regression of ocular melanoma metastatic to the liver after hepatic arterial chemoembolization with cisplatin and polyvinyl sponge. JAMA. 1988;260(7):974-976.

17. van den Bosch T, van Beek J, Kiliç E. Genetics of Uveal Melanoma. In: Armstrong A editor. Advances in Malignant Melanoma - Clinical and Research Perspectives. InTech. 2001. p. 137-158.

18. Triozzi PL, Eng C, Singh AD. Targeted therapy for uveal melanoma Cancer Treat Rev. 2008;34(3):247-258.

19. Kujala E, Mäkitie T, Kivelä T. Very long-term prognosis of patients with malignant uveal melanoma. Invest Ophthalmol Vis Sci. 2003;44(11):46514659.

20. Jovanovic P, Mihajlovic M, Djordjevic-Jocic J, et al. Ocular melanoma: an overview of the current status. Int J Clin Exp Pathol. 2013;6(7):12301244.

21. Cabello CM, Bair WB, Wondrak GT. Experimental therapeutics: targeting the redox Achilles heel of cancer. Curr Opin Investig Drugs. 2007;8(12):1022-1037.

22. Fruehauf JP, Meyskens FL. Reactive oxygen species: a breath of life or death? Clin Cancer Res. 2007;13(3):789-794.

23. Fruehauf JP, Trapp V. Reactive oxygen species: an Achilles' heel of melanoma? Expert Rev Anticancer Ther. 2008;8(11):1751-1757.

24. Meyskens FL, Farmer P, Fruehauf JP. Redox regulation in human melanocytes and melanoma. Pigment Cell Res. 2001;14(3):148-154.

25. Meyskens FL, Farmer PJ, Yang S, et al. New perspectives on melanoma pathogenesis and chemoprevention. Recent Results Cancer Res. 2007;174:191-195

26. González MJ, Mora E, Riordan NH. Rethinking vitamin C and cancer: an update on nutritional oncology. Cancer Prev Intl. 1988;3:215-224.

27. Yamamoto K, Takahashi M, Niki E. Role of iron and ascorbic acid in the oxidation of methyl linoleate micelles. Chem Lett. 1987;1:49-52.

28. Tsao CS, Dunhan WB, Leung PY. In vivo antineoplastic activity of ascorbic acid for human mammary tumour. In vivo. 1988;2(2):147-150.

29. Tsao CS, Dunhan WB, Leung PY. Effect of ascorbic acid and its derivatives on the growth of human mammary tumour xenografts in mice. Cancer J. 1989;5:53-59.

30. Poydock ME. Effect of combined ascorbic acid and B12 on survival of mice implanted with Ehrlich carcinoma and L1210 leukemia. Am J Clin Nutr. 1982;54(6 Suppl):1261s-1265s.

31. Edgar JA. Dehydroascorbic acid and cell division. Nature. 1970;227:24 26.

32. Bram S, Froussard P, Guichard M, et al. Vitamin C preferential toxicity for malignant melanoma cells. Nature. 1980;284(5757):629-631.

33. Riordan NH, Riordan HD, Meng XL, et al. Intravenous ascorbate as a tumour cytotoxic chemotherapeutic agent. Med Hypotheses. 1995;44(3):207-213. 
34. Sakagami H, Satoh K. Pro-oxidant action of two antioxidants: ascorbic acid and gallic acid. Anticancer Res. 1997;17(1A):221-224.

35. Makino Y, Sakagami H, Takeda M. Induction of cell death by ascorbic acid derivatives in human renal carcinoma and glioblastoma cell lines. Anticancer Res. 1999;19:3125-3132.

36. Nakamura Y, Yamafuji K. Antitumor activities of oxidized products of ascorbic acid. Sci Bull Fac Kyushu Univ. 1968;23:119-125.

37. Yamafuji K, Nakamura Y, Omura H, et al. Antitumor potency of ascorbic, dehydroascorbic or 2,3-diketogulonic acid and their action on deoxyribonucleic acid. Z Krebsforsh Klin Onkol Cancer Res Clin Oncol. 1971;76(1):1-7.

38. Omura H, Tomita Y, Yasuhiko N, et al. Antitumor potentiality of some ascorbate derivaties. J Fac Agr Kyushu Univ. 1974;18:181-189.

39. Peterkofsky B, Prather W. Cytotoxicity of ascorbate and other reducing agents towards cultured fibroblasts as a result of hydrogen peroxide formation. J Cell Physiol. 1971;90(1):61-70.

40. Clement MV, Ramalingam J, Long LH, et al. The in vitrocytotoxicity of ascorbate depends on the culture medium used to perform assay and involves hydrogen peroxide. Antiox Redox Signal. 2001;3:157-163.

41. González MJ, Schemmel RA, Dugan L, et al. Dietary fish oil inhibits human breast carcinoma growth: a function of increased lipid peroxidation. Lipids. 28(9):827-832.

42. Sakagami H, Satoh K, Hakeda Y, et al. Apoptosis-inducing activity of vitamin C and vitamin K. Cell Mol Biol (Noisy-le-grand). 2000;46(1):129143.

43. Iwasaka K, Koyama N, Nogaki A, et al. Role of hydrogen peroxide in cytotoxicity induction by ascorbates and other redox compounds. Anticancer Res. 1998;18(6A):4333-4337.

44. Muñoz E, Blazquez MV, Ortiz C, et al. Role of ascorbate in the activation of NF-KappaB by tumour necrosis factor-alpha in T-cells. Biochem J. 1997;325:23-28.

45. Halliwell B. Vitamin C: antioxidant or pro-oxidant in vivo? Free Red Res. 1996;25(5):439-454

46. Alcain FJ, Buron MI. Ascorbate on cell growth and differentiation. $J$ Bioenerg Biomembr. 1996;26(4) 393-398.

47. Asano K, Satoh K, Hosaka M, et al. Production of hydrogen peroxide in cancerous tissue by intravenous administration of sodium 5,6 benzylideneL-ascorbate. Anticancer Res. 1999;19(1A):229-236.

48. Avakawa N, Nemoto S, Suzuki E, et al. Role of hydrogen peroxide in the inhibitory effect of ascorbate on cell growth. J Nutr Sci Vitaminol (Tokyo). 1994;40(3):219-227.

49. Ohno S, Ohno Y, Suzuki N, et al. High-dose Vitamin C (Ascorbic Acid) Therapy in the Treatment of Patients with Advanced Cancer. Anticancer Res. 2009;29(3):809-816.

50. Davies KJ. The broad spectrum of responses to oxidants in proliferating cells: a new paradigm for oxidative stress. IUBMB Life. 1999;48(1):4147.

51. Dasgupta A, Zdunek T. In vitro lipid peroxidation of human serum catalyzed by cupric ion: antioxidant rather than pro-oxidant role of ascorbate. Life Sci. 1992;50:875-882.

52. Leung PY, Miyashita K, Young M, et al. Cytotoxic effect of ascorbate and its derivative on cultured malignant and non-malignant cell lines. Anticancer Res. 1993;13(2):47-80.

53. Iyanagi T, Yamazaki I, Anan KF. One-electron oxidation-reduction properties of ascorbic acid. Biochem Acta. 1985;806(2):255-261.
54. Venugopal M, Jamison JM, Gilloteaux J, et al. Synergistic antitumor activity of vitamins $\mathrm{C}$ and $\mathrm{K} 3$ on human urologic tumour cell lines. Life Sci. 1996;59(17):1389-1400.

55. Satoh K, Kadofuku T, Sakagami H. Copper but not iron, enhances apoptosis-inducing activity of antioxidants. Anticancer Res. 1997;17(4A):2487-2490.

56. Powers HJ, Gibson AT, Bates CJ, et al. Does vitamin C intake influence the rate of tyrosine catabolism in premature babies? Ann Nutr Metab. 1994;38(3):166-173.

57. Palumbo A, Misuraca G, D'Ischia M, et al. Effect of metal ions on the kinetics of tyrosine oxidation catalysed by tyrosinase. Biochem $\mathrm{J}$. 1985;288(3):647-651

58. Sun Y, Oberley LW, Oberley TD, et al. Lowered antioxidant enzymes in spontaneously transformed embryonic mouse liver cells in culture. Carcinogenesis. 1993;14(7):1457-1463.

59. Benade L, Howard T, Burk D. Synergistic killing of Ehrlich ascites carcinoma cells by ascorbate and 3-amino-1,2,4,-triazole. Oncology. 1969;23(1):33-43.

60. Punnonen K, Ahotupa M, Asaishi K, et al. Antioxidant enzyme activities and oxidative stress in human breast cancer. J Cancer Res Clin Oncol. 1994;120(6):374-377.

61. Jaruga P, Olinste R. Activity of antioxidant enzymes in cancer diseases. Postepy Hig Med Dosw. 1994;48(4):443-455.

62. Chen Q, Espey MG, Sun AY, et al. Ascorbate in pharmacologic concentrations selectively generates ascorbate radical and hydrogen peroxide in extracellular fluid in vivo. Proc Natl Acad Sci USA 2007;104(21):8749-8754.

63. Poydock ME. Effect of combined ascorbic acid and B12 on survival of mice implanted with Erlich carcinoma and L1210 leukemia. Am J Clin Nutr. 1982;54(6 Suppl):1261s-1265s.

64. Edgar JA. Dehydroascorbic acid and cell division. Nature. 1970;227:24 26.

65. Cameron E, Pauling L, Leibovitz B. Ascorbic acid and cancer: a review Cancer Res. 1979;39(3):663-681.

66. McCormick WJ. Cancer: a collagen disease, secondary to a nutritional deficiency? Arch Pediatr. 1959;76(4):166-171.

67. Lewin S. Vitamin C. Its molecular biology and medical potential. NY: Academic Press, USA. 1975.

68. Goetzl EJ, Wasserman SI, Gigli I, et al. Enhancement of random migration and chemotactic response of human leukocytes by ascorbic acid. J Clin Invest. 1974;53(3):813-818.

69. Siegel BV. Enhancement of interferon production by poly (r1), poly (rC) in mouse cell cultures by ascorbic acid. Nature. 1975;254:531-532.

70. Dahl H, Degre M. The effect of ascorbic acid on production of human interferon and the antiviral activity in vitro. Acta Pathol Scand Sect B. 1976;84B(5):280-284.

71. Beetens JR, Hermen AG. Ascorbic acid and Prostaglandin formation. Int $J$ Vitam Nutr Res. 1983;Suppl:131s-144s.

72. El Attar TM, Lin HS. Effect of vitamin $\mathrm{C}$ and Vitamin $\mathrm{E}$ on prostaglandin synthesis by fibroblasts and squamous carcinoma cells. Prostaglandins Leukot Essent Fatty Acids. 1992;47(4):253-257.

73. Reddy VG, Khanna D, Singh N. Vitamin C augments chemotherapeutic response of cervical carcinoma beta cells by stabilizing P53. Biochem Biophys Res Commun. 2001;282(2):409-415. 
74. Mirvish SS. Experimental evidence for inhibition of N-nitroso compound formation as a factor in a negative correlation between vitamin C consumption and the incidence of certain cancers. Cancers Res. 1994;54(7 Suppl):1948s-1951s

75. Friedman DL, Himelstein B, Shields CL, et al. Chemoreduction and local ophthalmic therapy for intraocular retinoblastoma. J Clin Oncol. 2000;18(1):12-17.

76. Rodriguez-Galindo C, Wilson MW, Haik BG, et al. Treatment of intraocular retinoblastoma with vincristine and carboplatin. J Clin Oncol. 2003;21(10):2019-2025.

77. Marees T, Moll AC, Imhof SM, et al. Risk of second malignancies in survivors of retinoblastoma: More than 40 years of follow-up. $J$ Nat Cancer Inst. 2008;100(24):1771-1779.

78. Rizzuti AE, Dunkel IJ, Abramson DH. The adverse events of chemotherapy for retinoblastoma: what are they? Do we know? Arch Ophthalmol. 2008;126(6):862-865.

79. Abramson DH. Benefits and Risks of Intraarterial Chemotherapy for Retinoblastoma: An Update. Retina Today. 2011.

80. Shields CL, Bianciotto CG, Jabbour P, et al. Intra-arterial chemotherapy for retinoblastoma: report No. 1, control of retinal tumours, subretina seeds, and vitreous seeds. Arch Ophthalmol. 2011;129(11):1399-1406.

81. Shields CL, Bianciotto CG, Jabbour P, et al. Intra-arterial chemotherapy for retinoblastoma: report No. 2, treatment complications. Arch Ophthalmol. 2011;129(11):1407-1415

82. Yamane T, Kaneko A, Mohri M. The technique of ophthalmic arterial infusion therapy for patients with intraocular retinoblastoma. Int $J$ Clin Oncol. 2004;9(2):69-73.

83. Gobin YP, Dunkel IJ, Marr BP, et al. Combined, sequential intravenous and intra-arterial chemotherapy (bridge chemotherapy) for young infants with retinoblastoma. PLoS One. 2012;7(9):e44322.

84. Schaiquevich P, Ceciliano A, Millan N, et al. Intra-arterial chemotherapy is more effective than sequential periocular and intravenous chemotherapy as salvage treatment for relapsed retinoblastoma. Pediatr Blood Cancer. 2012;60(5):766-770

85. Abramson DH, Dunkel IJ, Brodie SE, et al. A phase I/II study of direct intraarterial (ophthalmic artery) chemotherapy with melphalan for intraocular retinoblastoma initial results. Ophthalmology. 2008;115(8):1398-1404.

86. Vajzovic LM, Murray TG, Aziz-Sultan MA, et al. Clinicopathologic review of enucleated eyes after intra-arterial chemotherapy with melphalan for advanced retinoblastoma. Arch Ophthalmol. 2008;128(12):1619-1623.

87. Aziz HA, Boutrid H, Murray TG, et al. Supraselective injection of intraarterial melphalan as the primary treatment for late presentation unilateral multifocal stage $\mathrm{Vb}$ retinoblastoma. Retina. 2010;30(4 Suppl):S63-65

88. Kaneko A, Suzuki S. Eye-preservation treatment of retinoblastoma with vitreous seeding. Jpn J Clin Oncol. 2003;33(12): 601-607.

89. Inomata $\mathrm{M}$, Kaneko A. Chemosensitivity profiles of primary and cultured human retinoblastoma cells in a human tumour clonogenic assay. $J P N J$ Cancer Res. 1987;78(8):858-868.

90. Hoffman RM. In vitro sensitivity assays in cancer: a review, analysis, and prognosis. J Clin Lab Anal. 1991;5(2):133-143.

91. Hoffman RM. In vitro assays for chemotherapy sensitivity. Crit Rev Oncol Hematol. 1993;15(2):99-111.

92. Inomata $\mathrm{M}$, Kaneko A. In vitro chemosensitivity assays of retinoblastoma cells. Int J Clin Oncol. 9(1):31-35.
93. Liu Q, Wang Y, Wang H, et al. Tandem therapy for retinoblastoma: immunotherapy and chemotherapy enhance cytotoxicity on retinoblastoma by increasing apoptosis. J Cancer Res Clin Oncol. 2013;139(8):13571372 .

94. Wang YF, Kunda PE, Lin JW, et al. Cytokine-induced killer cells cocultured with complete tumour antigen-loaded dendritic cells, have enhanced selective cytotoxicity on carboplatin-resistant retinoblastoma cells. Oncol Rep. 2013;29(5):1841-1850.

95. Medina MA, Schweigerer L. A plasma membrane redox system in human retinoblastoma cells. Biochem Mol Biol Int. 1993;29(5):881-887.

96. Medina MA, García de Veas R and Schweigerer L. Ascorbic acid is cytotoxic for pediatric tumour cells cultured in vitro. Biochem $\mathrm{Mol}$ Biol Int. 1994;34(5):871-874.

97. Roomi MW, Roomi N, Bhanap B, et al. Antineoplastic activity of a nutrient mixture in Y-79 malignant retinoblastoma cells. Oncology Reports. 2013;29(1):29-33.

98. Mastrangelo D, Massai L, Micheli L, et al. High Doses of Ascorbate Kill Y79 Retinoblastoma Cells In vitro. J Clin Exp Ophthalmol. 2013;4:268.

99. Orjuela MA, Titievsky L, Liu X, et al. Fruit and vegetable intake during pregnancy and risk for development of sporadic retinoblastoma. Cancer Epidemiol Biomarkers Prev. 2005;14(6):1433-1440.

100. Adithi M, Nalini V, Krishnakumar S. The role of nitric oxide synthases and nitrotyrosine in retinoblastoma. Cancer. 2005;103(8):1701-1711.

101. Kandalam M, Mitra M, Subramanian K, et al. Molecular pathology of retinoblastoma. Middle East Afr J Ophthalmol. 2010;17(3):217-223.

102. Deepa PR, Nalinib V, Mallikarjunab K, et al. Oxidative Stress in Retinoblastoma: Correlations with Clinicopathologic Features and Tumor Invasiveness. Curr Eye Res. 2009;34(12):1011-1018.

103. Frenkel S, Nir I, Hendler K, et al. Long-term survival of uvea melanoma patients after surgery for liver metastases. $\mathrm{Br} J$ Ophthalmol. 2009;93(8):1042-1046.

104. Pflugfelder A, Kochs C, Garbe C, et al. S3-guideline "diagnosis, therapy and follow-up of melanoma" -- short version. J Dtsch Dermatol Ges. 2013;11(6):563-594.

105. Singh AD, Turell ME, Topham AK. Uveal melanoma: trends in incidence, treatment, and survival. Ophthalmology. 2011;118(9):1881-1885.

106. Diener-West M, Reynolds SM, Agugliaro DJ, et al. Development of metastatic disease after enrollment in the COMS trials for treatment of choroidal melanoma: Collaborative Ocular Melanoma Study Group Report No. 26. Arch Ophthalmol. 2005;123(12):1639-1643.

107. Augsburger JJ, Correa ZM, Shaikh AH. Effectiveness of treatments for metastatic uveal melanoma. Am J Ophthalmol. 2009;148(1):119-127.

108. Buder K, Gesierich A, Gelbrich G, et al. Systemic treatment of metastatic uveal melanoma: review of literature and future perspectives. Cancer Med. 2013;2(5):674-686.

109. http://www.cancer.org/acs/groups/cid/documents/webcontent/003063pdf.pdf

110. http://www.nccn.org/patients/guidelines/melanoma/files/assets/common/ downloads/files/melanoma.pdf

111. Jovanovic P, Mihajlovic M, Djordjevic-Jocic J, et al. Ocular melanoma: an overview of the current status. Int J Clin Exp Pathol. 2013;6(7):12301244.

112. Majdi M, Milani BY, Movahedan A, et al. The Role of Ultraviolet Radiation in the Ocular System of Mammals. Photonics. 2014;1(4):347368. 
113. Denat L, Kadekaro AL, Marrot L, et al. Melanocytes as Instigators and Victims of Oxidative Stress. J Invest Dermatol. 2014;134(6):1512-1518.

114. Meierjohann S. Oxidative stress in melanocyte senescence and melanoma transformation. Eur J Cell Biol. 2014;93(1-2):36-41.

115. Venza M, Visalli M, Beninati C, et al. Cellular Mechanisms of Oxidative Stress and Action in Melanoma. Oxid Med Cell Longev. 2015;2015:481782.

116. Ibañez IL, Notcovich C, Policastro LL, et al. Reactive Oxygen Species in the Biology of Melanoma. Breakthroughs in Melanoma Research", book Edited by Yohei Tanaka, 2011. ISBN 978-953-307-291-3, p. 642.

117. Kim KB, Bedikian AY, Camacho LH, et al. A Phase II Trial of Arsenic Trioxide in Patients with Metastatic Melanoma. Cancer. 2015;104(8):1687-1692.

118. Mastrangelo D, Massai L, Valyi-Nagy K, et al. Megadoses of Ascorbate as a New Chemotherapeutic Approach in Uveal Melanoma: A Preliminary In Vitro Investigation. J Clin Exp Ophthalmol. 2013;4:6.

119. Wilson MK, Bagueley BC, Wall C, et al. Review of high-dose intravenous vitamin C as an anticancer agent. Asia-Pacific J Clin Oncol. 2014;10:2237.

120. Park S. The Effects of High Concentrations of Vitamin C on Cancer Cells. Nutrients. 2013;5(9):3496-3505.
121. Gonzalez MJ, Miranda-Massari JR, Duconge J, et al. Increasing the Effectiveness of Intravenous Vitamin $\mathrm{C}$ as an Anticancer Agent. JOM. 2015;30(1):45-50.

122. Warburg O. On the origin of cancer cells. Science. 1956;123(3191):309314.

123. Dakubo GD. Mitochondrial genetics and cancer. XV, 356p., Hardcover. ISBN: 978-3-642-11415-1, Springer. 2010.

124. Barron C, Tsiani E, Tsakiridis T. Expression of the glucose transporters GLUT1, GLUT3, GLUT4 and GLUT12 in human cancer cells. BMC Proceedings. 2012;6(Suppl 3):P4.

125. Meseure D, Alsibai KD. Cancer Metabolic and Immune Reprogramming: The Intimate Interaction Between Cancer Cells and Microenvironment. $J$ Cancer Prev Curr Res. 2014;1(2):00006.

126. Annibaldi A, Widmann C. Glucose metabolism in cancer cells. Curr Opin Clin Nutr Metab Care. 2010;13(4):466-470.

127. Hsu PP, Sabatini DM. Cancer Cell Metabolism: Warburg and Beyond. Cell. 2008;134(5):703-707.

128. Yeluri S, Madhok B, Prasad KR, et al. Cancer's craving for sugar: an opportunity for clinical exploitation. J Cancer Res Clin Oncol. 2009;135(7):867-877. 